\title{
Kinerja Wakil Kepala Sekolah Menengah Pertama dilihat dari Tugas Pokok dan Fungsinya
}

\author{
Sulistia Paudi*, Ikhfan, Arifin Suking \\ Universitas Negeri Gorontalo, Gorontalo, Indonesia
}

Corresponding author: Sulistia Paudi (e-mail: sulistyapaudi06@gmail.com)

\begin{abstract}
Abstrak: Tujuan penelitian ini yaitu mendeskripsikan kinerja wakil kepala sekolah (wakasek) bidang kurikulum, kesiswaan, sarana prasarana, dan hubungan masyarakat (humas) di Sekolah Menengah Pertama (SMP) Negeri se-Kecamatan Suwawa Kabupaten Bone Bolango. Kinerja tersebut dilihat dari keterlaksanaan tugas pokok dan fungsi jabatan wakasek. Data penelitian ini dikumpulkan melalui angket, wawancara, dan dokumentasi. Hasil penelitian menunjukkan bahwa kinerja: (1) wakasek bidang kurikulum berada pada kategori "baik", (2) wakasek bidang kesiswaan berada pada kategori "sangat baik", (3) wakasek bidang sarana dan prasarana berada pada kategori "sangat baik", dan (4) wakasek bidang humas berada pada kategori "baik". Hasil penelitian menyarankan kepada kepala sekolah untuk (1) melakukan pemantauan kepada setiap wakasek dalam mengerjakan tugas pokok dan wewenang mereka, (2) mengevaluasi setiap program yang dilaksanakan oleh masing-masing wakasek, (3) meningkatkan kebaikan komunikasi dengan wakasek (4) dan melaksanakan pemotivasian.
\end{abstract}

Kata kunci: kinerja, jabatan wakil kepala sekolah, tugas pokok dan fungsi wakil kepala sekolah

\section{Performance of The Vice Principals of Junior High Schools Viewed from Their Main Duties}

\begin{abstract}
The purpose of this study was to describe the performance of the vice principals in the fields of curriculum, student affairs, infrastructure, and public relations $(P R)$ in Public Junior High Schools in Suwawa District, Bone Bolango Regency. The performance was viewed from their main duties. The research data were collected using questionnaires, interviews, and documentation. The results showed that the performance of the vice principals of the curriculum, students affairs, facilities and infrastructure, and public relations was in good, very good, very good, and good category respectively. The results of the study suggested that the principals of the studied schools should (1) monitor their vice principals in carrying out their main tasks and responsibilities, (2) evaluate the implementation of school programs managed by their vice principals, (3) develop more effective communication with their vice principals (4) and provide work motivation.
\end{abstract}

Keywords: performance, vice principal, vice principal main duties and role 


\section{PENDAHULUAN}

Kemampuan kepala sekolah untuk mempengaruhi orang lain agar mau bekerjasama dalam mencapai tujuan sekolah yang telah ditetapkan sebelumnya sangat dibutuhkan. Kemampuan kepemimpinan kepala sekolah dan pengaruh kepemimpinan tersebut merupakan salah satu yang mendukung keberhasilan siswa (Darling-Hammond, LaPointe, Meyerson, \& Orr, 2007; Heck \& Hallinger, 2014; Marzano, Waters, \& McNulty, 2005). Kepala sekolah memegang peran penting dalam manajemen, bahkan dapat dinyatakan sebagai inti dari manajemen. Hal ini sejalan yang dikemukakan Grunert (2005) yang menyatakan bahwa perilaku kepemimpinan kepala sekolah mencakup kepemimpinan kolaboratif, kolaborasi guru, pengembangan profesional, asosiasi tujuan, dukungan kejuruan dan kemitraan belajar. Birgitta Wistrand dalam (Cooper, 2002) mengatakan bahwa kepemimpinan hakikatnya adalah mengalirkan energi. Transmisi energi inilah yang memungkinkan pemimpin menjadi seorang pengarah sekaligus penggerak bagi stafnya agar bekerja dengan standar kualitas terbaik demi pencapaian tujuan lembaga. Namun kesuksesan kepala sekolah tentu tidak terlepas dari dukungan para wakil kepala sekolah, karena wakil tersebut merupakan perpanjang tangan kepala sekolah dalam menjalankan berbagai bidang di sekolah. Hal tersebut sejalan dengan studi Ontario yang mengemukakan bahwa wakil kepala sekolah sebagai perpanjangan tangan dari kepala sekolah mendapatkan beban kerja yang bertambah karena banyaknya pelaksanaan dari level kebijakan Kementerian Pendidikan, harapan komite sekolah, dan rencana peningkatan sekolah (Leithwood \& Azah, 2014).

Salah satu urgensi meneliti isu tentang kinerja wakil kepala sekolah adalah bahwa belum banyak penelitian yang mengkaji isu tersebut ketika peran dan fungsi dari para wakil kepala sekolah sangat penting di sekolah. Hampir sebagian besar tugas-tugas manajerial kepala sekolah ditangani oleh para wakil kepala sekolah. Beban kerja kepala sekolah yang sangat tinggi dapat berimplikasi kepada menurunnya kinerja organisasi. Hal ini senada dengan pandangan Goleman dan Boyatzis (2003) bahwa terdapat beberapa faktor yang menyebabkan kinerja organisasi dan individu menurun yaitu beban kerja yang berlebihan, terlalu banyak pekerjaan yang harus dilaksanakan, waktu yang singkat, dan hampir tidak ada dukungan. Maka dari itu kepala sekolah harus mempunyai jiwa kepemimpinan untuk mendorong bawahan dalam melakukan pekerjaan. Jadi, peran wakil kepala sekolah perlu dimaksimalkan, karena menurut Rintoul \& Goulais (2010) sebagian besar peran kepala sekolah didelegasikan kepada wakil kepala sekolah. Pekerjaan yang didelegasikan terutama berhubungan dengan operasional sekolah dan tugas instruksional.

Berdasarkan uraian tersebut maka penulis tertarik mengkaji tentang bagaimana kinerja 
wakil kepala sekolah di Sekolah Menengah Pertama Negeri se-Kecamatan Suwawa. Tujuan kajian ini adalah untuk mengetahui mengetahui kinerja wakil kepala sekolah (wakasek) bidang kurikulum, kesiswaan, sarana prasarana, dan hubungan masyarakat (humas) di Sekolah Menengah Pertama (SMP) Negeri se-Kecamatan Suwawa Kabupaten Bone Bolango.

\subsection{Tugas pokok dan fungsi jabatan}

Tugas pokok dan fungsi jabatan membutuhkan uraian pekerjaan yang jelas agar pekerja atau pegawai yang menduduki jabatan tersebut mengetahui tugas, tanggung jawab, dan standar yang harus dicapai dalam jabatannya. Uraian pekerjaan yang jelas ini dikenal dengan deskripsi pekerjaan. Robbins \& Judge (2012) mengatakan bahwa deskripsi pekerjaan merupakan daftar tugas, kewajiban dan tanggung jawab yang diperlukan oleh pekerjaan tertentu, dan satu definisi mengatakan bahwa deskripsi pekerjaan adalah identifikasi tugas, kewajiban dan tanggung jawab dari sebuah pekerjaan. Menurut Miwaukee dan Sidney dalam (Mathis \& Jackson, 2006) untuk melihat apakah deskripsi kerja sudah sesuai dengan harapan karyawan digunakan model analisis pekerjaan fungsional, yang terdiri dari sasaran organisasi, apa yang dapat dilakukan karyawan untuk mencapai sasaran itu dalam pekerjaan mereka, tingkat dan orientasi apa yang dilakukan para tenaga kerja, standar deskripsi pekerjaan dan pelatihan.

Menurut Hasibuan (2014) indikator deskripsi pekerjaan meliputi: (a) identifikasi pekerjaan atau jabatan, (b) hubungan tugas dan tanggung jawab, yakni perincian tugas dan tanggung jawab secara nyata diuraikan secara terpisah agar jelas diketahui, (c) standar wewenang dan pekerjaan, yakni kewenangan dan prestasi yang harus dicapai oleh setiap pejabat harus jelas, (d) syarat kerja harus diuraikan dengan jelas, (e) ringkasan pekerjaan atau jabatan, hendaknya menguraikan bentuk umum pekerjaan dengan mencantumkan fungsifungsi dan aktivitas utamanya, (f) penjelasan tentang jabatan yang berada di bawah maupun atasnya. Tujuan deskripsi pekerjaan yaitu: (a) konsistensi pekerjaan menjamin kehidupan bisnis yang teratur, (b) keberhasilan atau kegagalan semua organisasi tergantung pada prinsip adanya jabatan yang benar yang dilakukan oleh orang-orang yang benar dengan cara-cara yang benar. Adapun manfaat deskripsi pekerjaan yaitu: (a) membantu atasan dan bawahan mengerti: mengapa suatu jabatan diadakan dan apa tujuan utamanya, (b) sebagai alat manajemen untuk mengintegrasikan fungsi-fungsi: performance management, staffing and selection, organization design, reward system, career development \& training. 


\subsection{Wakil kepala sekolah: jabatan manajemen tingkat menengah}

Pada umumnya, suatu organisasi memiliki tiga level manajemen yaitu manajemen tingkat atas (top level management), manajemen tingkat menengah (middle level management) dan manajemen tingkat pertama (first level management). Ketiga tingkatan manajemen ini membentuk sebuah hirarki yang digolongkan berdasarkan urutan seberapa pentingnya dalam suatu organisasi.

Pemimpin menengah dalam organisasi sekolah (wakasek bidang akademik, kesiswaan, sarana prasarana, dan hubungan masyarakat) memainkan peran penting dalam mengembangkan dan mempertahankan sifat dan kualitas pengalaman belajar siswa. Cara mereka melakukan hal tersebut sangat dipengaruhi oleh keadaan di mana mereka bekerja. Tingkatan pada manajemen level menengah berada pada posisi antara manajemen lini pertama dan manajemen puncak. Tingkatan manajemen ini memiliki tanggung jawab atas pelaksanaan rencana yang telah ditetapkan oleh manajemen puncak. Manajemen tingkat menengah mempunyai tanggung jawab pula terhadap segala kegiatan yang dilaksanakan oleh tingkatan manajemen di bawahnya bahkan terhadap beberapa karyawan operasional.

Manajemen tingkat menengah pada suatu organisasi (1) memerlukan keterampilan manajerial serta kemampuan teknis, (2) menjadi perantara antara manajemen puncak dan manajemen lini pertama, (3) merencanakan rencana jangka menengah antara 1-5 tahun, (4) berkoordinasi dengan departemen yang ada berdasarkan seluruh kegiatan yang dilakukan, (5) menjalankan perintah, kebijakan, dan rencana yang ditetapkan oleh manajemen puncak, (6) bertanggung jawab secara langsung kepada manajemen puncak seperti dewan direksi dan CEO perusahaan, dan (7) memberi saran atau rekomendasi kepada manajemen puncak sesuai dengan kondisi yang ada.

Pada konteks tulisan ini, manajemen tingkat menengah adalah wakil kepala sekolah (wakasek). Wakasek tersebut bertanggung jawab kepada top level management yakni kepala sekolah. Menurut Permendikbud Nomor 6 Tahun 2019 tentang Pedoman Organisasi dan Tata Kerja Satuan Pendidikan Dasar dan Menengah, pada Pasal 12, susunan organisasi di SMP terdiri atas: (a) kepala sekolah, (b) wakil kepala sekolah, (c) kelompok jabatan fungsional; dan (d) kelompok jabatan pelaksana. Wakasek sebagaimana yang dimaksud pada ayat 1 huruf b, paling banyak 4 orang, yaitu pada bidang akademik, kesiswaan, hubungan masyarakat, dan sarana prasarana. 


\section{METODE PENELITIAN}

Jenis penelitian yang digunakan adalah kuantitatif. Sampel penelitian ini adalah middle leader atau wakil kepala sekolah dan para guru. Penelitian ini dilaksanakan di Sekolah Menengah Pertama se-Kecamatan Suwawa Kabupaten Bone Bolango Provinsi Gorontalo. Populasi dalam penelitian ini adalah seluruh guru di SMP se-Kecamatan Suwawa yang berjumlah 121 guru. Penentuan anggota sampel pada penelitian ini menggunakan teknik simple random sampling. Besarnya anggota sampel menggunakan rumus Slovin yaitu:

$\mathrm{n}=\frac{N}{1+N(e)^{2}}$

Dimana:n = ukuran sampel/jumlah responden

$\mathrm{N}=$ kuran populasi

$\mathrm{e}=$ kelonggaran kesalahan pengambilan sampel yang masih bisa ditolerir; $\mathrm{e}=0,1$

maka $n=\frac{121}{1+\left(121.0,1^{2}\right)}=\frac{121}{1+(121.0,01)}=\frac{121}{2,21}=54.75$ dibulatkan menjadi 55 orang

Untuk penyebaran anggota sampel dapat dilihat pada tabel berikut:

Tabel 1. Sebaran anggota sampel

\begin{tabular}{llll}
\hline Nama sekolah & Jumlah guru & Perhitungan & Jumlah sampel \\
\hline SMP Negeri 1 Suwawa & 26 & $26 / 121 \times 55$ & 11.81 \\
SMP Negeri 2 Suwawa & 26 & $26 / 121 \times 55$ & 11.81 \\
SMP Negeri 3 Suwawa & 11 & $11 / 121 \times 55$ & 5 \\
SMP Negeri 1 Suwawa Tengah & 10 & $10 / 121 \times 55$ & 4.54 \\
SMP Negeri 1 Suwawa Selatan & 9 & $9 / 121 \times 55$ & 4.09 \\
SMP Negeri 2 Suwawa Selatan & 9 & $9 / 121 \times 55$ & 4.09 \\
SMP Negeri 1 Suwawa Timur & 14 & $14 / 121 \times 55$ & 6.36 \\
SMP Negeri 2 Suwawa Timur & 10 & $10 / 121 \times 55$ & 4.54 \\
SMP Negeri 3 Suwawa Timur & 6 & $6 / 121 \times 55$ & 2.72 \\
\hline Jumlah & 121 & & 55 \\
\hline
\end{tabular}

Sumber: Dinas Pendidikan dan Kebudayaan Bone Bolango 2020

Teknik pengumpulan data menggunakan angket, wawancara dan dokumentasi. Teknik analisis data menggunakan teknik persentase. Skor yang diperoleh setiap indikator menunjukan kinerja wakil kepala sekolah. Cara menentukannya dengan mengadopsi pendapat Thoha (2003) bahwa apabila capaian 91-100\% termasuk kategori sangat baik, 81-90\% kategori baik, 71-80\% kategori cukup baik, 61-70\% kategori kurang baik, dan apabila capaian kurang dari 60\% dikategorikan tidak baik

\section{HASIL}

Hasil penelitian ini mendeskripsikan kinerja wakil kepala sekolah, yaitu: 1) wakasek bidang kurikulum, 2) wakasek bidang kesiswaan, 3) wakasek bidang sarana dan prasarana, dan 4) 
wakasek bidang hubungan masyarakat yang terdapat di SMP Negeri se-Kecamatan Suwawa Kabupaten Bone Bolango yang dijelaskan berikut ini.

\subsection{Kinerja wakasek bidang kurikulum}

Indikator kinerja wakasek bidang kurikulum terdiri dari empat deskriptor yakni (1) menyusun perencanaan kurikulum, (2) pengarahan penyusunan perangkat mengajar, (3) penilaian pembelajaran, dan (4) penyusunan laporan, untuk skor capaian deskriptor tersebut disajikan pada tabel di bawah ini:

Tabel 2. Indikator kinerja wakasek bidang kurikulum

\begin{tabular}{lllll}
\hline No & Deskriptor & Skor & Persentase (\%) & Kriteria \\
\hline 1 & Menyusun perencanaan kurikulum & 1292 & 93,96 & sangat baik \\
2 & Pengarahan penyusunan perangkat pembelajaran & 987 & 89,72 & baik \\
3 & Penilaian pembelajaran & 679 & 83.30 & baik \\
4 & Penyusunan laporan & 463 & 84,18 & baik \\
\hline & Rata-rata & 3421 & 88,57 & baik \\
\hline
\end{tabular}

Tabel 2 menunjukkan bahwa kinerja wakasek bidang kurikulum dalam menyusun perencanaan kurikulum memperoleh skor 1292 atau 93,96 \% termasuk kategori sangat baik, kinerja wakasek bidang kurikulum dalam memberikan pengarahan dalam penyusunan perangkat pembelajaran memperoleh skor 987 atau 89,72\% termasuk kategori baik. Kinerja wakasek bidang kurikulum dalam memberikan penilaian pembelajaran memperoleh skor 679 atau 83,30\% termasuk kategori baik. Selanjutnya, kinerja wakasek bidang kurikulum dalam menyusun laporan memperoleh skor 463 atau 84,18\% termasuk kategori baik. Dengan demikian, rata-rata kinerja wakasek bidang kurikulum memperoleh skor 3421 atau 88,57\% termasuk kategori baik.

\subsection{Kinerja wakasek bidang kesiswaan}

Indikator kinerja wakasek bidang kesiswaan terdiri dari enam deskriptor yakni (1) menyusun jadwal kegiatan pembinaan siswa, (2) memberikan pengarahan kepada perangkat penerimaan peserta didik baru (PPDB), (3) membina pengurus OSIS, (4) membina pelaksanaan tata tertib sekolah, (5) membuat program kegiatan siswa, dan (6) membuat laporan kegiatan kesiswaan. Perolehan nilai masing-masing deskriptor dapat dilihat pada tabel 3 berikut ini: 
Tabel 3. Indikator kinerja wakasek bidang kesiswaan

\begin{tabular}{lllll}
\hline No & Deskriptor & Skor & Persentase (\%) & Kriteria \\
\hline 1 & Menyusun jadwal kegiatan pembinaan siswa & 718 & 87,03 & Baik \\
2 & Memberikan pengarahan kepada perangkat PPDB & 515 & 93,36 & Sangat baik \\
3 & Pembinaan pengurus OSIS & 510 & 92,72 & Sangat baik \\
4 & Pembinaan tata tertib sekolah & 551 & 92,90 & Sangat baik \\
5 & Membuat program kegiatan siswa & 758 & 91,87 & Sangat baik \\
6 & Membuat laporan kegiatan kesiswaan. & 488 & 88,72 & Baik \\
\hline & Rata-rata & 3548 & 91,94 & Sangat baik \\
\hline
\end{tabular}

Tabel 3 menunjukkan bahwa kinerja wakasek bidang kesiswaan dalam menyusun jadwal kegiatan pembinaan siswa memperoleh skor 718 atau 87,03\% termasuk kategori sangat baik. Kinerja wakasek bidang kesiswaan dalam memberikan pengarahan penerimaan peserta didik baru (PPDB) memperoleh skor 515 atau 93,36\% termasuk kategori sangat baik dan kinerja wakasek bidang kesiswaan dalam melakukan pembinaan kepada pengurus OSIS memperoleh skor 510 atau 92,72\% termasuk kategori sangat baik. Sedangkan kinerja wakasek bidang kesiswaan dalam pembinaan tata tertib sekolah memperoleh skor 551 atau 92,90\% termasuk kategori sangat baik. Kinerja wakasek bidang kesiswaan dalam membuat program kegiatan siswa memperoleh skor 758 atau 91,87\% termasuk kategori sangat baik dan kinerja wakasek bidang kesiswaan dalam membuat laporan kegiatan kesiswaan memperoleh skor 488 atau $88,72 \%$ termasuk kategori baik. Nilai rata-rata kinerja wakasek bidang kesiswaan memperoleh skor 3548 atau 91,94\% termasuk kategori sangat baik.

\subsection{Kinerja wakasek bidang sarana dan prasarana.}

Indikator kinerja wakasek bidang sarana dan prasarana terdiri dari tiga deskriptor yakni: (1) menyusun program sarana dan prasarana, (2) menginventarisasi sarana dan prasarana, dan (3) pendayagunaan sarana dan prasarana. Hasil perolehan nilai masing-masing deskriptor dapat dilihat pada tabel berikut:

Tabel 4. Indikator kinerja wakasek bidang sarana dan prasarana

\begin{tabular}{llllc}
\hline No & Deskriptor & Skor & Persentase (\%) & Kriteria \\
\hline 1 & Menyusun program sarana dan prasarana & 775 & 93,93 & Sangat baik \\
2 & Menginventarisasi sarana dan prasarana, & 790 & 95,75 & Sangat baik \\
3 & Pendayagunaan sarana dan prasarana & 1753 & 91,06 & Sangat baik \\
\hline$\quad$ Rata-rata & 3318 & 92,81 & Sangat baik \\
\hline
\end{tabular}

Tabel 4 menunjukkan bahwa kinerja wakasek bidang sarana dan prasarana dalam menyusun program sarana dan prasarana memperoleh skor 775 atau 93,93\% termasuk kategori sangat baik, kinerja wakasek bidang sarana dan prasarana dalam kegiatan menginventarisasi sarana dan prasarana memperoleh skor 790 atau 95,75\% termasuk kategori sangat baik, kinerja wakasek bidang sarana dan prasarana dalam melakukan pendayagunaan sarana dan prasarana 
memperoleh skor 1753 atau 91,06\% termasuk kategori sangat baik. Dengan demikian, rata-rata kinerja wakasek bidang sarana dan prasarana memperoleh skor 3318 atau 92,81\% termasuk kategori sangat baik.

\subsection{Kinerja wakasek bidang hubungan sekolah dengan masyarakat.}

Indikator kinerja wakasek bidang hubungan sekolah dengan masyarakat terdiri dari empat deskriptor yakni: (1) menyusun dan melaksanakan program hubungan sekolah dengan masyarakat, (2) membangun kemitraan sekolah, (3) mempublikasikan program kegiatan sekolah, dan (4) menyusun laporan. Hasil perolehan nilai masing-masing deskriptor dapat dilihat pada tabel berikut:

Tabel 5. Indikator kinerja wakasek bidang hubungan sekolah dengan masyarakat

\begin{tabular}{lllll}
\hline No & Deskriptor & Skor & Persentase (\%) & Kriteria \\
\hline 1 & Penyusunan dan pelaksanaan program hubungan & 917 & 83,38 & Baik \\
& sekolah dengan masyarakat & & & \\
2 & Membangun kemitraan sekolah & 1405 & 85,15 & Baik \\
3 & Mempublikasikan program kegiatan sekolah & 474 & 86,18 & Baik \\
4 & Penyusunan laporan & 226 & 82,18 & \\
\hline$\quad$ Rata-rata & 3575 & 84,53 & Baik \\
\hline
\end{tabular}

Tabel 5 menunjukkan bahwa kinerja wakasek bidang sarana dan prasarana dalam menyusun dan menjalankan program hubungan sekolah dengan masyarakat memperoleh skor 917 atau 83,38\% termasuk kategori baik dan kinerja wakasek hubungan sekolah dengan masyarakat dalam membangun kemitraan sekolah memperoleh skor 1405 atau 85,15\% termasuk kategori baik. Selanjutnya, kinerja wakasek bidang hubungan sekolah dengan masyarakat dalam mempublikasikan program kegiatan sekolah memperoleh skor 474 atau $86,18 \%$ termasuk kategori baik, dan kinerja wakasek bidang hubungan sekolah dengan masyarakat dalam menyusun laporan memperoleh skor 226 atau 82,18\% termasuk kategori baik. Pada aspek ini, rata-rata kinerja wakasek bidang hubungan sekolah dengan masyarakat memperoleh skor 3575 atau 84,53\% termasuk kategori baik.

\section{PEMBAHASAN}

Berdasarkan hasil penelitian tentang kinerja wakasek khususnya dalam tugas pokok dan fungsinya di SMP Negeri, pada bagian ini akan dibahas setiap kinerja wakasek tersebut yaitu (1) bidang kurikulum, (2) bidang kesiswaan, (3) bidang sarana dan prasarana, serta (4) bidang hubungan sekolah dengan masyarakat yang diuraikan sebagai berikut: 


\subsection{Kinerja wakasek bidang kurikulum}

Hasil penelitian terkait dengan indikator kinerja wakasek bidang kurikulum menunjukkan capaian $85,57 \%$ termasuk dalam kategori baik. Ini menunjukan bahwa capaian kinerja wakasek bidang kurikulum perlu dipertahankan atau ditingkatkan sesuai tupoksinya. Para wakasek harus mampu menyesuaikan tuntutan kinerja yang harus dilaksanakan. Salah satu yang mendukung kebaikan kinerja wakasek adalah integritas dan tanggung jawab yang harus ditanamkan kepada diri masing-masing wakil kepala sekolah.

Tanggung jawab yang diberikan kepala sekolah kepada wakasek bidang kurikulum merupakan bentuk kepercayaan atasan. Khairunnisa (2008) mengatakan bahwa tanggung jawab merupakan suatu akibat lebih jauh dari pelaksanaan peranan, hak, kewajiban, dan kekuasaan. Hasil penelitian itu sejalan dengan hasil studi Ontario yang menemukan bahwa wakil kepala sekolah bekerja rata-rata 54,5 jam seminggu, disibukkan dengan tugas operasional sekolah, dengan hanya 2,4 jam seminggu yang dikhususkan untuk kurikulum dan kepemimpinan instruksional (Pollock, Wang, \& Hauseman, 2017). Beberapa ahli berpandangan bahwa tugas operasional sekolah yang dijalankan kepala sekolah dan wakil kepala sekolah menjadi lebih menantang karena kompleksitas yang berkembang dari pertemuan sosial siswa yang beragam, emosional, dan kebutuhan akademis (Alberta Teachers Association, 2014; Pollock, Wang, \& Hauseman, 2014). Oleh karena itu, peran wakil kepala sekolah sebagai (a) pelaksana tugas yang diberikan oleh kepala sekolah, dan (b) pelaksana tugas kepala sekolah ketika kepala sekolah tidak hadir di sekolah (Ontario Ministry of Education, 1990).

Hasil penelitian ini juga memberikan perhatian bahwa idealnya program yang dibuat oleh bidang kurikulum sejalan dengan program yang dibuat oleh bidang yang lain misalnya program pembimbingan siswa. Pada hal ini, wakasek bidang kurikulum wajib membuat dan mengembangkan program tersebut karena sangat diperlukan oleh wakasek bidang kesiswaan untuk melaksanakan pembimbingan siswa. Dengan demikina wakasek bidang kurikulum merancang program, wakasek bidang kesiswaan yang melakukan pembimbingan sesuai dengan arahan dari wakasek bidang kurikulum.

\subsection{Kinerja wakasek bidang kesiswaan}

Hasil penelitian pada indikator ini diperoleh persentase dengan 91,94\% termasuk kategori sangat baik. Hal ini menunjukan bahwa kinerja atau uraian pekerjaan dan tanggung jawab yang diemban oleh wakasek bidang kesiswaan sudah sesuai dengan tupoksi yang telah ditetapkan. 
Seperti yang dikemukakan oleh Noe (2014) bahwa "job description is a list of the task, duties, and responsibilities (TRDS) that a particular job entails". Pendapat tersebut menyebutkan bahwa deskripsi pekerjaan adalah sebuah daftar tugas, kewajiban dan tanggung jawab yang diperlukan oleh pekerjaan tertentu. Hal senada yang dikemukakan oleh Robbins \& Judge (2012) bahwa deskripsi pekerjaan adalah identifikasi tugas, kewajiban dan tanggung jawab dari sebuah pekerjaan. Tidak hanya itu, secara garis besar dapat dikatakan bahwa deskripsi jabatan atau pekerjaan menggambarkan secara rinci tentang tugas-tugas tanggung jawab, dan kewajiban suatu jabatan tertentu yang akan menggambarkan pula tentang apa yang harus dikerjakan, bagaimana cara mengerjakannya, dan mengapa pekerjaan tersebut harus dilakukan.

Berdasarkan hal tersebut maka suatu deskripsi jabatan atau pekerjaan akan memberikan informasi tentang isi suatu jabatan, membantu menghindari adanya kebingungan dan memberikan pemahaman atau penjelasan. Selain itu, gambaran-gambaran yang jelas mengenai tanggung jawab akan menunjang efektivitas kerja dan kepuasan kerja. Pada penelitian ini, hasil yang dicapai oleh wakasek bidang kesiswaan menunjukkan hasil positif dalam mendukung pencapaian tujuan sekolah, namun capaian tersebut masih memerlukan pengawasan dan evaluasi agar capaian tersebut dapat dipertahankan dan bila perlu ditingkatkan.

\subsection{Kinerja wakasek bidang sarana dan prasarana}

Hasil penelitian berkaitan dengan indikator kinerja wakasek bidang sarana dan prasarana menunjukkan capaian $92,81 \%$ yang berada pada kategori sangat baik. Hasil ini mengindikasikan bahwa kinerja wakasek bidang sarana dan prasarana sudah dijalankan dengan baik. Pentingnya pengelolaan sarana dan prasarana sejalan dengan dikemukakan oleh Ikawati (2018) bahwa pengelolaan sarana dan prasarana pembelajaran yang ada di suatu sekolah juga akan baik dan efisien apabila dapat didukung oleh sumber daya manusia yang profesional. Hal tersebut senada dengan hasil penelitian Rahayu (2016) bahwa pemberdayaan sarana dan prasarana di sekolah sangat besar pengaruhnya terhadap peningkatan akademik siswa. Kemajuan teknologi pendidikan sekarang yang selalu mengandalkan IPTEK untuk siswa berimplikasi terhadap sekolah untuk semaksimal mungkin melengkapi fasilitas sarana dan prasarana pendidikan dan dapat memberdayakannya sesuai dengan fungsinya. Lebih lanjut, Ikawati (2018) menjelaskan bahwa setiap sarana dan prasarana pembelajaran yang ada di dalam sebuah sekolah perlu dikelola dengan sebaik-baiknya secara bertahap dan berkelanjutan agar dapat memenuhi standar yang telah ditetapkan oleh pemerintah. Hal itu dikarenakan berfungsi atau tidaknya sarana dan prasarana pembelajaran tersebut akan sangat menentukan 
keberhasilan proses pembelajaran.

Louis (2019) mejelaskan bahwa peran wakil kepala sekolah terdiri dari pengadministrasian berbagai operasi sekolah dan tugas kepemimpinan instruksional seperti yang ditugaskan oleh kepala sekolah. Secara khusus, peran tersebut telah berkembang menjadi pelaksana tugas operasional sekolah yang interaktif dan baik. Tugas kepemimpinan instruksional berkaitan dengan upaya meningkatkan pembelajaran dan prestasi siswa. Dalam hal ini peran wakil kepala sekolah adalah (a) mengembangkan dan memperkuat sumber daya kepemimpinan pribadi, (b) memprioritaskan operasi sekolah dan tugas kepemimpinan instruksional, dan (c) berjuang untuk keseimbangan kehidupan kerja.

Lebih lanjut Rahayu (2016) mengemukakan bahwa kepala sekolah dalam pemberdayaan sarana dan prasarana dibantu wakil kepala sekolah bidang sarana dan prasarana, mulai dari kegiatan perencanaan, pengelolaan keuangan, pengadaan barang bergerak dan barang tidak bergerak, program monitoring, evaluasi, dan pelaporan serta rencana tindak lanjut. Dalam memaksimalkan pengelolaan sarana dan prasarana di sekolah, maka diperlukan kerja sama antara kepala sekolah dengan wakil kepala sekolah bidang sarana dan prasarana serta para wakil kepala sekolah bidang yang lain. Hasil yang baik pada penelitian ini perlu dipertahankan dan ditingkatkan oleh wakasek bidang sarana dan prasarana mengingat keberadaan sarana dan prasarana sangat vital dan penting dalam mendukung pencapaian tujuan pembelajaran di sekolah.

\subsection{Kinerja wakasek bidang hubungan masyarakat}

Hasil penelitian pada indikator ini memperoleh $84,53 \%$ termasuk kategori baik. Hasil ini menunjukan bahwa kinerja wakasek bidang hubungan dengan masyarakat sudah memenuhi syarat dalam ukuran efektivitas suatu pekerjaan. Untuk mengukur kinerja dalam pekerjaan bukanlah suatu hal yang sangat sederhana, namun harus dikaji dari berbagai sudut pandang dan tergantung pada siapa yang menilai serta menginterpretasikannya. Pernyataan tersebut seperti yang dikemukakan oleh Martani dan Lubis (2003) yang menjelaskan bahwa kriteria untuk mengukur efektivitas suatu organisasi ada tiga pendekatan yang dapat digunakan. Pertama, pendekatan sumber yakni mengukur efektivitas dari input, pendekatan mengutamakan adanya keberhasilan organisasi untuk memperoleh sumber daya, baik fisik maupun nonfisik yang sesuai dengan kebutuhan organisasi. Kedua, pendekatan proses adalah untuk melihat sejauh mana efektivitas pelaksanaan program dari semua kegiatan proses internal atau mekanisme organisasi. Terakhir, pendekatan sasaran dimana pusat perhatian pada output, mengukur 
keberhasilan organisasi untuk mencapai hasil (output) yang sesuai dengan rencana.

Hasil penelitian yang menunjukkan kategori baik, tentu merupakan hasil peningkatan yang telah dilakukan oleh wakasek bidang hubungan masyarakat. Akan tetapi, pencapaian tersebut masih memerlukan evaluasi pada beberapa indikator yang ada. Pada indikator memberikan informasi tentang perkembangan sekolah dan mempublikasikan kebijakan atau program sekolah kepada pihak luar, masih ada sebagian sekolah yang belum melaksanakannya dengan baik. Tentunya hal tersebut perlu menjadi perhatian dari pihak sekolah untuk terus mendorong wakasek bidang hubungan masyarakat dalam melaksanakan tugas pokoknya.

\section{SIMPULAN}

Hasil kajian dapat disimpulkan bahwa kinerja wakil kepala sekolah dilihat dari sisi kinerja wakasek bidang kurikulum sudah dijalankan sesuai tupoksinya dengan baik dan dapat dikategorikan baik. Kinerja wakasek bidang kesiswaan sudah sangat baik dan sesuai dengan tupoksi yang diembannya. Selanjutnya, wakasek bidang sarana dan prasarana dikategorikan sangat baik. Hasil ini mengindikasikan bahwa kinerja wakasek bidang sarana dan prasarana sudah dijalankan dengan sangat baik, dan wakasek bidang hubungan dengan masyarakat sudah memenuhi syarat dalam ukuran baik. Penelitian ini merekomendasikan pemantauan, koordinasi dan komunikasi yang baik antara kepala sekolah dengan wakil kepala sekolah.

\section{Acknowledgement}

Ucapan terima kasih kepada Kepala Dikbud Kab. Bone Bolango atas izin yang diberikan kepada penulis untuk pengumpulan data, serta kepada para kepala sekolah dan wakil kepala sekolah SMP Negeri se Kec. Suwawa atas berkenannya menjadi menjadi responden. 


\section{DAFTAR PUSTAKA}

Alberta Teachers' Association. (2014). A week in the life of alberta school leaders. New York: Edmonton.

Cooper, R.K. \& Sawaf, A. (2002). Executive eq, kecerdasan emosional dalam kepemimpinan dan organisasi. Jakarta: Gramedia Pustaka Utama.

Darling-Hammond, L., LaPointe, M., Meyerson, D., \& Orr, M. T. (2007). Preparing school leaders for a changing world: Lessons from exemplary leadership development programs. Stanford, CA: Stanford University.

Dinas Pendidikan dan Kebudayaan Bone Bolango. (2020). Profil dinas pendidikan dan kebudayaan bone bolango "dalam angka". Gorontalo: Dinas Pendidikan dan Kebudayaan

Goleman, D. (2003). Kecerdasan emosional. Jakarta: Gramedia Pustaka Utama.

Gruenert (2005). Correlations of collaborative school cultures with student achievement. NASSP Bulletin Journal, 88(645), 43-53.

Hasibuan, M.S.P. (2014) Manajemen sumber daya manusia. Jakarta: PT Bumi Aksara.

Hariandja, M.T.E. (2002). Manajemen sumber daya manusia. Jakarta: Grasindo

Heck, R., \& Hallinger, P. (2014). Modeling the longitudinal effects of school leadership on teaching and learning. Journal of Educational Administration, 52(5), 653-681. doi: 10.1108/JEA-08- 2013-0097

Ikawati, A. (2018) Pengelolaan sarana dan prasarana pembelajaran produktif di SMK Negeri 3 Makassar. Tesis tidak dipublikasikan. Pascasarjana UNM: Makassar

Khairunnisa. (2008). Kedudukan, peran dan tanggung jawab hukum direksi. Medan: Pasca Sarjana USU

Leithwood, K., \& Azah, V. N. (2014). Secondary principals' and vice-principals' workload study: Final report. $\quad$ Retrieved http://www.edu.gov.on.ca/eng/policyfunding/memos/nov2014/

FullSecondaryReportOctober7_EN.pdf

Louis, L. (2019). Work intensification and the secondary vice-principal role. Canadian Journal of Educational Administration and Policy, 190, 64-72.

Marzano, R., Waters, T., \& McNulty, B. (2005). School leadership that works. from research to results. Colorado: McREL.

Mathis, R.L. \& J.H. Jackson. 2006. Human resource management: manajemen sumber daya manusia. Jakarta: Salemba Empat.

Noe, (2014). Pengaruh job descriptiondan job specification terhadap job description proses. Journal Efisiensi UNY

Ontario Ministry of Education. (1990). Education act: Regulation 298 operations of schools general. Retrieved from https://www.ontario.ca/laws/regulation/900298

Kemendikbud (2009) Permendikbud Nomor 6 Tahun 2019 tentang Pedoman Organisasi dan Tata Kesatuan Pendidikan Dasar dan Menengah. Jakarta: Kemendikbud

Pollock, K., Wang, F., \& Hauseman, C. (2014). The changing nature of principals' work: Final report for the Ontario principals' Council. Ontario: Principal Council

Pollock, K., \& Wang, F., \& Hauseman, D. C. (2017). The changing nature of vice principals' work: Final report for the Ontario Principals' Council. Ontario: Principal Council

Rahayu, Dwi (2016). Keterampilan manajerial kepala sekolah dalam pemberdayaan sarana dan prasarana pendidikan (studi kasus pada madrasah aliyah negeri 1 Banjarmasin).Tesis tidak dipublikasikan. Banjarmasin: Pascasarjana Institut Agama Islam Negeri (IAIN) Antasari 
Rintoul, H. M., \& Goulais, L. (2010). Vice principalship and moral literacy: Developing a moral compass. Journal of Educational Management Administration \& Leadership, 38(6), 745-757.

Robbins, S. P \& Judge. T. A. (2012). Organizational behavior. New Jersey: Pearson Education Thoha, C.M. 2003. Teknik evaluasi pendidikan. Jakarta: Raja Grafindo Persada. 